\title{
PERBEDAAN HASIL BELAJAR BIOLOGI SISWA KELAS X PADA PENERAPAN MODEL PEMBELAJARAN THINK, TALK, WRITE (TTW) DAN MODEL PEMBELAJARAN SURVEY, QUESTION, READ, REFLECT, RECITE, REVIEW (SQ4R) DI MADRASYAH ALIYAH
}

\author{
Widyastuti , Mahrus, Nur Lestari \\ Program Studi Pendidikan Biologi, Jurusan Pendidikan MIPA, FKIP Universitas Mataram \\ *Email: astutiw841@gmail.com
}

Diterima: 12 Desember 2018. Disetujui: 10 Juni 2019. Dipublikasikan: 30 Juli 2019

\begin{abstract}
Abstrak: Penelitian ini bertujuan untuk mengetahui perbedaan hasil belajar siswa Kelas X pada penerapan model pembelajaran Think, Talk, Write (TTW) den model pembelajaran Survey, Question, Read, Reflect, Recite, Review (SQ4R) di MA Al-Aziziyah Putri Kapek Gunungsari Tahun Ajaran 2017/2018. Jenis penelitian ini adalah penelitian quasi eksperimen dengan desain penelitian Pretest Postest Non Equivalent Control Group Design. Populasi penelitian seluruh siswa kelas X MA Al-Aziziyah Putri Gunungsari. Penentuan sampel dilakukan dengan teknik purposive sampling. Instrumen yang digunakan untuk mengukur hasil belajar kognitif sebanyak 25 butir soal pilihaan ganda dan 5 butir soal essay, sedangkan untuk mengukur hasil belajar afektif dan psikomotorik digunakan lembar penilaian afektif dan psikomotorik. Data hasil tes belajar biologi dianalisis menggunakan uji-t separated varians pada taraf kepercayaan 95\% dengan bantuan SPSS 17.0 for Windows sehingga diperoleh nilai signifikansi sebesar $0,001<\alpha=0,05$. Hal ini membuktikan bahwa terdapat perbedaan hasil belajar biologi siswa yang menggunakan model pembelajaran kooperatif tipe TTW dengan model pembelajaran SQ4R di MA Al-Aziziyah Putri Kapek Gunungsari Tahun Ajaran 2017/2018.
\end{abstract}

Kata Kunci : Model Pembelajaran TTW, Model Pembelajaran SQ4R, Hasil Belajar.

Abstract: The aim of this research is to know the difference of learning achievment of class X students on the application of learning model of Think, Talk, Write (TTW) and Survey, Question, Read, Reflect, Recite, Review (SQ4R) model at MA Al-Aziziyah Putri Kapek Gunungsari in the academic year of 2017/2018. The research is quasi experimental research with Pretest Postest Non Equivalent Control Group Design. The research populations were all students of grade X MA Al-Aziziyah Putri Gunungsari. Determination of sample was done by technique of purposive sampling. Instruments used to measure cognitive learning achiement were 25 items of multiple choice and 5 items essay, while to measure the results of affective and psychomotor learning used assessment sheets. The data of cognitive learning achivment were analyzed by using t-test separated variance at $95 \%$ confidence level with the help of SPSS 17.0 for Windows the significance value was $0,001<\alpha=0,05$. This mean that there were differences of students' biology learning achievement using cooperative learning model of Think, Talk, Write (TTW) type with Survey, Question, Read, Reflect, Recite, Review (SQ4R) learning model at MA Al-Aziziyah Putri Kapek Gunungsari.

Keywords : TTW Learning Model, SQ4R Learning Model, Learning Outcomes.

\section{PENDAHULUAN}

Pendidikan adalah bimbingan atau pertolongan yang diberikan pada anak oleh orang dewasa secara sengaja agar anak menjadi dewasa. Kedewasaan anak ditentukan oleh kebudayaannya. Pendidikan juga diartikan sebagai usaha manusia untuk membina kepribadiannya sesuai dengan nilai-nilai dalam masyarakat dan kebudayaan [1]. Hamdani [2] mengatakan bahwa pendidikan dalam masyarakat bertujuan untuk mensejajarkan status kehidupan masyarakat. Tanpa pendidikan yang adil dan merata, status kesejajaran sosial tidak akan mudah dicapai.

Dipdiknas [3] Dalam Undang Undang Nomor 20 Tahun 2003 tentang sistem pendidkan nasioanal, pasal 1 ayat 1 disebutkan bahwa "pendidikan adalah usaha sadar dan terencana untuk mewujudkan suasana belajar dan proses pembelajaran agar siswa secara aktif mengembangkan potensi dirinya untuk memiliki kekuatan spiritual keagamaan, pengendalian diri, kepribadian, kecerdasan, akhlak mulia, serta keterampilan yang diperlukan dirinya, masyarakat dan Negara“. Pembelajaran tersebut tentu tidak hanya mengacu pada keberhasilan pembelajaran itu sendiri. Sejalan dengan itu, paradigma pembelajaran yang berpusat pada guru (teaching centered) harus berubah menjadi paradigma pembelajaran yang berpusat pada siswa (student centered). Pembelajaran berpusat pada siswa mengubah peran guru sebagai sumber belajar menjadi peran fasilitator, artinya guru lebih banyak membantu sisiwa dalam belajar [4-6]. 
Menurut Widoyoko [7], proses pembelajaran merupakan salah satu bentuk program, karena pembelajaran yang baik memerlukan perencanaan yang matang dan dalam pelaksanaannya melibatkan berbagai orang, baik guru ataupun siswa yang memiliki keterkaiatan antara kegiatan pembelajaran yang lain, yaitu untuk mencapai kompetensi bidang studi yang pada akhirnya untuk mendukung pencapaian kompetensi lulusan, serta berlangsung dalam organisasi.

Purwanta [8] mengatakan bahwa hasil belajar merupakan suatu kegiatan guru selama rentang pembelajaran yang berkaitan dengan pengambilan keputusan tentang pencapaian kompetensi siswa yang memiliki karakteristik individual yang unik. Hasil belajar kognitif diartikan sebagai nilai yang diperoleh siswa setelah mengikuti pembelajaran melalui tes yang bekenaan dengan objek kognitif yang meliputi aspek pengetahuan atau ingatan, pemahaman, aplikasi, analisis, sintesis, dan evaluasi. Hasil belajar merupakan hal yang dapat dipandang dari dua sisi yaitu sisi siswa dan dari sisi guru.

Seiring dengan perkembangan ilmu pengetahuan dan teknologi menyebabkan proses pembelajaran menjadi lebih mudah untuk dilakukan karena tidak adanya batasan untuk belajar sehingga siswa memiliki banyak waktu dalam memahami materi, tetapi harus diikuti pula dengan inovasi yang diberikan oleh guru terhadap proses belajar mengajar. Saat ini banyak sekali model pembelajaran yang inovatif, menyenangkan, menantang dan mampu memotivasi siswa untuk belajar sehingga guru lebih mudah dalam menyampaikan materi pembelajaran, diantaranya adalah model pembelajaran kooferatif tipe Think Talk Write (TTW) dan model pembelajaram Survey, Question, Read, Reflect, Recite, Review (SQ4R).

Model pembelajaran TTW merupakan suatu model pembelajaran untuk melatih keterampilan siswa dalam menulis. TTW menekankan perlunya peserta didik mengkomunikasikan hasil pemikirannya [9]. Basri [10] menyimpulkan bahwa hasil penelitian yang dilakukan menunjukan setelah dilakukan perbandingan hasil pretest dan posttest maka dapat diketahui bahwa hasil belajar siswa mengalami peningkatan setelah dilaksanakan pembelajaran dengan menggunakan model pembelajaran TTW. Kusumaningrum [11] melaporkan bahwa model pembelajaran TTW berpengaruh signifikan terhadap hasil belajar siswa. Hal itu dikarenakan model pembelajaran TTW memberikan kesempatan kepada siswa untuk berfikir aktif dalam pembelajaran, serta mampu mebuat siswa mengkonstruksikan pengetahuannya sendiri.

Prasetyani [12] berpendapat bahwa pembelajaran SQ4R adalah cara membaca yang dapat mengembangkan metakognitif siswa, yaitu dengan menugaskan siswa untuk membaca bahan belajar secara seksama. Kegiatan membaca bukan hanya melafalkan tulisan, namun juga memahami isi dari bacaan tersebut serta melibatkan aktivitas lainnya seperti aktivitas visual, berpikir, psikolinguistik dan metakognitif. Kegiatan ini membatu siswa untuk memperoleh pengetahuan awal yang baik secara mandiri [13]. Rahayu [14] melaporkan bahwa penerapan model pembelajaran SQ4R berbasis keterampilan berpengaruh terhadap hasil belajar IPA siswa kelas V SD Gugus Lotkal Wisnu Denpasar Utara. Berarti terdapat berpedaan signifkan hasil belajar IPA antara kelompok siswa yang mengikuti pembelajaran dengan model pembelajran SQ4R dengan yang mengikuti pembelajaran konvensional. Laporan peneliti lainnya melaporkan bahwa penerapan pembelajaran SQ4R mampu membantu meningkatkan hasil belajar sejarah siswa kelas VII SMP Empu Tantular Semarang [15].

kedua model pembelajaran tersebut samasama memberi kesmpatan pada siswa untuk memperoleh pemahaman konsep yang lebih mendalam, sehingga perlu dilakukan penelitian untuk mengetahui model manakah yang lebih efektif dalam mencapai hasil belajar siswa. Penelitian ini dilakukan untuk mengetahui "Perbedaan Hasil Belajar Biologi Kelas X pada Penerapan model pembelajaran TTW dengan model pembelajaran SQ4R di MA Al-Aziziyah Putri Kapek Gunungsari Tahun Ajaran 2017/2018.

\section{METODE PENELITIAN}

Jenis penelitian ini adalah quasi eksperiment (experimen semu) dengan desain yang digunakan dalam penelitian ini adalah Pretestpostest non-equivalent control group design. Penelitian ini dilaksanakan di MA Al Aziziyah Putri Kapek Gunungsari pada kelas XB dan XF pada semester ganjil tanggal 15 November - 2 Desember 2017 tahun ajaran 2017/2018 dengan variable bebas model pembelajaran kooperatif tipe TTW dan model pembeljaran SQ4R dan variable terikat hasil belajar siswa. Populasi dalam penelitian ini adalah seluruh siswa kelas X MA Al Aziziyah Putri Gunungsari yang terdiri dari enam kelas dengan yang berjumlah 177 siswa. Sampel penelitian diambil dengan teknik purposive sampling, yaitu teknik penentuan sampel dengan pertimbangan tertentu, sampel yang diteliti diambil dengan cara menentukan 2 kelas yang memiliki rata-rata nilai ulangan harian biologi yang rendah sehingga diperoleh kelas X.B dijadikan kelas eksperimen I yang diterapkan model pembelajaran kooperatif tipe TTW dengan jumlah 25 siswa dan kelas X.F dijadikan kelas eksperimen II yang diterapkan model pembelajaran SQ4R dengan jumlah 31 siswa. Instrument yang digunakan dalam 
penelitian ini adalah tes objektif dan subjektif yang telah diuji validitasnya menggunakan teknik korelasi bivariate Product Moment dan uji reliabilitas ditentukan dengan teknik Croanbach's Alpha dalam program SPSS 17 for windows. Data dianalisis dengan menggunakan uji Independent Sample t-Test dengan bantuan program SPSS 17 for Windows dengan ketentuan sudah melakukan uji persyaratan yaitu uji normalitas dan homogenitas.

\section{HASIL DAN PEMBAHASAN}

Hasil belajar kognitif siswa untuk pretest diperoleh hasil yang relative sama antara kelas yang menggunakan model pembelajaran TTW dan kelas dengan menggunakan model pembelajaran SQ4R. Pre-test yang telah dilakukan pada kelas X.B yang menggunakan model TTW diperoleh nilai terendah 20 dan nilai tertinggi 55 dengan nilai rata-rata 39,2, sedangkan untuk kelas X.F yang menggunakan model $S Q 4 R$ diperoleh nilai terendah siswa adalah 20 dan nilai tertinggi adalah 55, dengan nilai rata-rata 39,4. Berdasarkan data pretest tersebut dapat dilihat bahwa hasil belajar kedua kelas menunjukkan nilai rata-rata yang masih rendah sebelum diberikan pembelajaran dengan model TTW dan SQ4R.

Setelah dilakukan pembelajaran menggunakan model TTW dan SQ4R terjadi peningkatan hasil belajar yang cukup tinggi. Data post-test menunjukan bahwa rata-rata tes akhir kelas yang menggunakan model TTW lebih tinggi bila dibandingkan dengan kelas yang menggunakan model pembelajaran SQ4R. Pada kelas X.B yang menggunakan model TTW diperoleh nilai terendah 60 dan nilai tertinggi 95 dengan nilai rata-rata 79,4, sedangkan pada kelas X.F diperoleh nilai terendah siswa adalah 55 dan nilai tertinggi adalah 85 , dengan nilai rata-rata 70,3. Berdasarkan data yang diperoleh dari pelaksanaan pre-test dan post-test dari kedua kelas, maka diketahui bahwa peningkatan nilai hasil belajar kelas yang menggunakan model TTW lebih tinggi dibandingkan kelas yang menggunakan model SQ4R. Hasil tersebut terlihat pada selisih peningkatan nilai rata-rata kelas TTW lebih tinggi daripada SQ4R, yaitu 40,2, dan 30,95. Untuk lebih jelasnya, perbandingan hasil belajar kognitif kedua model pembelajaran divisualisasikan pada Gambar 1 .

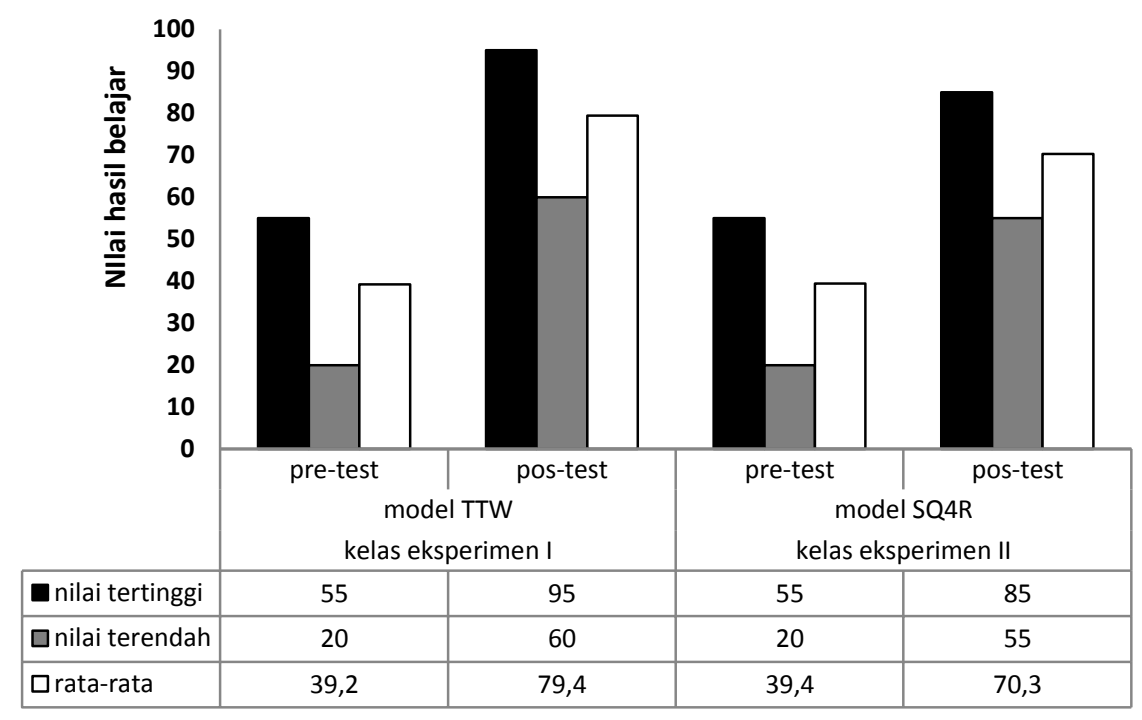

Gambar 1. Perbandingan hasil belajar kognitif Model TTW dan SQ4R

Penilaian afektif menggunakan lembar observasi dan diperoleh persentase nilai afektif pada kelas XB yang menggunakan model TTW sebanyak $0 \%$ berkategori kurang, $28 \%$ berkategori cukup, $40 \%$ kategori baik, dan $32 \%$ berkategori sangat baik. Kelas XF dengan penerapan model SQ4R diperoleh hasil presentase sebanyak 0\% berkategori sangat kurang, 0\% kurang, 29,03\% cukup baik, $48,38 \%$ berkategori baik, dan sebanyak $22,58 \%$ berkategoti sangat baik.
Tabel 1 menunjukkan bahwa kategori yang memiliki persentase paling tinggi pada kelas model TTW maupun kelas model SQ4R yaitu pada kategori baik, persentase kedua kelas berturut-turut $40 \%$ dan 48,38\%. Penilaian psikomotorik menggunakan lembar observasi dan diperoleh persentase nilai pada kelas XB yang menggunakan model $T T W$ sebanyak $0 \%$ berkategori sangat kurang, $0 \%$ berkategori kurang, $16 \%$ berkategori cukup baik, $56 \%$ berkategori baik, dan $28 \%$ beraktegori sangat baik. Kelas yang menggunakan 
model SQ4R diperoleh $0 \%$ berkategori sangat kurang $0 \%$ berkategori kurang, 29,03\% berkategoroi cukup baik, 58,06\% berkategori baik dan $12,9 \%$ berkategori sangat baik. Perbandingan nilai psikomotorik pada kedua model tersebut dapat dilihat pada Tabel 2.

Tabel 3 menunjukkan bahwa persentase kedua kelas sangat baik pada empat pertemuan. Kelas dengan model pembelajaran $T T W$ pada pertemuan pertama memperoleh skor 23 yang berarti pada pertemuan pertama ada satu langkah pembelajaran yang tidak dilakukan. Pada pertemuan kedua memperoleh skor 21, yang berarti ada 3 langkah pembelajaran yang tidak dilakukan. Pada pertemuan ketiga skor yang diperoleh berjumlah 24, dan pada pertemuan ke empat memperoleh 23 skor. Pada kelas dengan model pembelajaran $S Q 4 R$ menunjukkan pada pertemuan pertama nilainya sebesar 90,5 , pertemuan kedua memperoleh nilai 95,5, sedangkan pada pertemuan ketiga dan keempat memperoleh nilai 100. Hal ini menunjukkan keterlaksaan RPP pada kedua kelas termasuk dalam kategori sangat bagus.

Keterlaksanaan proses pembelajaran diukur dengan menggunakan lembar keterlaksanaan RPP yang diamati oleh observer. Pengamatan dilakukan untuk mengetahui apakah proses pembelajaran yang berlangsung sesuai dengan yang direncanakan pada RPP atau tidak.

Tabel 1. Perbandingan nilai afektif model TTW dan SQ4R

\begin{tabular}{cccccc}
\hline \multirow{2}{*}{ Rentang } & \multirow{2}{*}{ Kategori } & \multicolumn{2}{c}{ Model TTW } & \multicolumn{2}{c}{ Model SQ4R } \\
\cline { 3 - 6 } & & $\begin{array}{c}\text { Jumlah } \\
\text { Siswa }\end{array}$ & Persentase (\%) & $\begin{array}{c}\text { Jumlah } \\
\text { Siswa }\end{array}$ & Persentase (\%) \\
\hline $81-100$ & Sangat Baik & 8 & $32 \%$ & 7 & $22,58 \%$ \\
$61-80$ & Baik & 10 & $40 \%$ & 15 & $48,38 \%$ \\
$41-60$ & Cukup Baik & 7 & $28 \%$ & 9 & $29,03 \%$ \\
$21-40$ & Kurang & 0 & $0 \%$ & 0 & $0 \%$ \\
$\leq 20$ & Sangat Kurang & 0 & $0 \%$ & 0 & $0 \%$ \\
\hline
\end{tabular}

Tabel 2. Perbandingan nilai psikomotorik model TTW dan SQ4R

\begin{tabular}{cccccc}
\hline \multirow{2}{*}{ Rentang } & \multirow{2}{*}{ Kategori } & \multicolumn{2}{c}{ Model TTW } & \multicolumn{2}{c}{ Model SQ4R } \\
\cline { 3 - 6 } & & Sumlah & $\begin{array}{c}\text { Persentase } \\
(\%)\end{array}$ & $\begin{array}{c}\text { Jumlah } \\
\text { Siswa }\end{array}$ & $\begin{array}{c}\text { Persentase } \\
(\%)\end{array}$ \\
\hline \multirow{2}{*}{$81-100$} & Sangat Baik & 7 & $28 \%$ & 4 & $12,9 \%$ \\
$61-80$ & Baik & 14 & $56 \%$ & 18 & $58,06 \%$ \\
$41-60$ & Cukup Baik & 4 & $16 \%$ & 9 & $29,03 \%$ \\
$21-40$ & Kurang & 0 & $0 \%$ & 0 & $0 \%$ \\
$\leq 20$ & Sangat Kurang & 0 & $0 \%$ & 0 & $0 \%$ \\
\hline
\end{tabular}

Tabel 3 Persentase Keterlaksanaan Proses Pembelajaran

\begin{tabular}{lcccccccc}
\hline & \multicolumn{3}{c}{$\begin{array}{c}\text { Kelas Eksperimen I } \\
\text { (Model TTW) }\end{array}$ Kriteria Penilaian } & \multicolumn{3}{c}{ Pertemuan } & \multicolumn{3}{c}{$\begin{array}{c}\text { Kelas Eksperimen II } \\
\text { (Model SQ4R) }\end{array}$} \\
\cline { 2 - 9 } & I & II & III & IV & I & II & III & IV \\
\cline { 2 - 9 } Jumlah Pernyataan & 24 & 24 & 24 & 24 & 26 & 26 & 26 & 26 \\
Jumlah Skor & 23 & 21 & 24 & 23 & 23 & 25 & 26 & 26 \\
Skor Maksimal & 24 & 24 & 24 & 24 & 26 & 26 & 26 & 26 \\
Nilai & 95,8 & 87,5 & 100 & 95,8 & 88,5 & 96,2 & 100 & 100 \\
\hline Kategori & SB & SB & SB & SB & SB & SB & SB & SB \\
\hline
\end{tabular}


Uji $\mathrm{t}$ dilakukan setelah melakukan uji persyartan yaitu uji normalitas dan homogenitas. Uji hipotesis dilakukan setelah melakukan uji persyaratan yaitu uji normalitas dan uji homogenitas data. Uji persyaratan dilakukan untuk mengetahui apakah analisis data dapat dilanjutkan atau tidak. Uji persyaratan menunjukkan bahwa data hasil belajar siswa terdistribusi normal, tetapi varian data tidak homogen, sehingga uji hipotesis yang digunakan yaitu uji t separated varians. Hasil uji-t diperoleh nilai signifikansi sebesar $0,001<\alpha=$ 0,05 . Sesuai dengan kriteria pengujian hipotesis, dilihat dari hasil perhitungan uji-t berarti $\mathrm{H}_{0}$ ditolak dan $\mathrm{H}_{\mathrm{a}}$ diterima. Hal ini membuktikan bahwa terdapat perbedaan hasil belajar biologi siswa yang menggunakan model pembelajaran kooperatif tipe TTW dengan model pembelajaran SQ4R.

Hasil Penelitian menunjukan bahwa terdapat perbedaan hasil belajar Biologi siswa pada penerapan model kooperatif tipe TTW dan SQ4R, dimana siswa yang mengikuti pembelajaran dengan model pembelajaran TTW memiliki nilai rata-rata yang lebih tinggi dari siswa yang mengikuti pelajaran dengan model SQ4R. Hal tersebut dapat disebabkan oleh adanya perbedaan karakter masing-masing model pembelajaran tersebut. Model pembelajaran kooperatif tipe TTW memiliki keunggulan dan kekurangan seperti halnya model pembelajaran SQ4R. Keunggulan model pembelajaran kooperatif tipe TTW memiliki langkah-langkah pembelajaran yang singkat dan mudah dipahami oleh siswa dalam membelajarkan, selain itu siswa juga dapat dengan mudah menerapkan model pembelajaran tersebut sehingga memungkinkan siswa untuk terlibat secara optimal selama proses pembelajaran sehingga proses kognitif siswa dapat dikembangkan dan selanjutnya dapat mengkonstruksinya menjadi suatu keterampilan berpikir.

Penelitian yang sudah dilakukan dengan menggunakan model pembelajaran TTW, peserta didik lebih terlihat aktif dalam proses pembelajaran. Peserta didik juga lebih cepat menguasai materi yang diajarkan sehingga hasil hasil belajarpun meninggkat dari sebelumnya. Hasil yang diperoleh adalah sebesar 79,4 untuk nilai pre-test dari rata-rata awal hasil belajar Biologi siswa yaitu sebesar 39,2, sedangkan siswa yang mengikuti pembelajaran dengan model pembelajaran $S Q 4 R$ memiliki nilai rata-rata pre-test sebesar 70,3 dari rata-rata awal hasil belajar Biologi siswa yaitu sebesar 39,4. Selisih rata-rata kelas yang menggunakan model TTW adalah 40,2, selisih rata-rata tersebut lebih tinggi dibandingkan dengan kelas yang menggunakan model SQ4R yaitu 30,96. Hal itu sesuai dengan pendapat Herliani [16], dimana dalam penelitiannya menyimpulkan bahwa penerapan model TTW meningkatkan hasil belajar dan kemampuan berpikir kritis siswa yang memiliki kemampuan tingkat tinggi dan kemampuan tingkat rendah pada mata pelajaran biologi di SMA Negeri 8 Samarinda. Rojiah [17] juga mengatakan bahwa kemampuan berkomunikasi matematis siswa yang menggunkan model pembelajaran TTW lebih baik dibandingkan siswa yang menggunakan model konvensioanal. Model pembelajaran merupakan salah satu faktor penting untuk mencapai keberhasilan dalam proses pembelajaran. Karena dengan model pembelajaran proses pembelajaran akan lebih menarik dan menyenangkan [18].

Model pembelajaran TTW merupakan model pembelajran kooperatif yang dapat merangsang siswa untuk menjadi lebih aktif dalam mengkonstruksikan atau membangun pemahamannya secra mandiri. Model ini lebih dikenal dengan pembelajaran individu dalam kelompok. Model pembelajaran TTW memiliki keunggulan yaitu : meningkatkan kemampuan siswa dalam berkomunuikasi secara tulis, membantu sisiwa untuk meningkatkan aktivitas verbalnya pada saat berdiskusi, dan membantu siswa untuk melatih daya pikirnya menjadi lebih baik lagi. Model pembelajaran TTW ini merupakan strategi yang bertujuan mendorong siswa untuk berpikir, berbicara, dan kemudian menuliskan suatu topik tertentu. model pembelajaran TTW adalah model pembelajaran yang melatih siswa untuk mampu membangun pemikiran dalam menciptakan ide, mengungkapkan ide dan berbagi ide dengan temannya, dan menulis hasil pemikiranya tersebut dalam proses belajar. Strategi ini ditujukan untuk meningkatkan kemampuan peserta didik dalam menyelesaikan suatu permasalahan kemudian diungkapkan kepada rekannya untuk mencari solusi dari permasalahan yang ada, selain itu model ini juga memberikan kesempatan kepada semua peserta didik untuk terlibat secara aktif dalam proses belajar mengajar.

Berbeda dengan model TTW model pembelajaran SQ4R didalam proses pembelajaran melalui beberapa sintak yang dianggap cukup rumit bagi siswa dan lebih panjang bila di bandingkan dengan sintak pada model TTW, akan tetapi model pembelajaran SQ4R juga mempunyai kelebihankelebihan dalam meningkatkan kemampuan belajar siswa, dapat meningkatkan kemampuan berfikir siswa, serta memudahkan siswa untuk menghafal materi yang diajarkan guru. Beberapa kelebihan model SQ4R di atas dapat meningkatkan hasil belajar Biologi siswa jika dilihat dari rata-rata pretest yaitu sebesar 39,4 dan post-test sebesar 70,3 dimana rata-rata hasil belajar dapat meningkat sebesar 30,96.

Model pembelajaran SQ4R adalah strategi membaca yang dapat mengembangkan metakognitif siswa, yaitu dengan menugaskan siswa untuk membaca bahan belajar secara 
bersama-sama dan cermat. Meski terkesan sangat mekanistik, tetapi membaca dengan menggunakan $S Q 4 R$ ini dianggap dapat memuaskan, karena dengan metode ini dapat mendorong seseorang untuk lebih memahami apa yang dibacanya, terarah pada intisari atau kandungan-kandungan pokok yang tersirat dan tersurat dalam suatu buku atau teks. Selain itu, langkah-langkah yang ditempuh dalam metode ini tampaknya sudah menggambarkan prosedur ilmiah, sehingga diharapkan setiap informasi yang dipelajari dapat tersimpan dengan baik dalam sistem memori jangka panjang seseorang [19].

Hasil penelitian menunjukan bahwa metode SQ4R efektif dalam pembelajaran keterampilan membaca. Keefektifan ini dapat dilihat dari peningkatan nilai rata-rata peserta didik kelas eksperimen. Dengan menggunakan metode SQ4R peserta didik menjadi lebih aktif di dalam kelas. Bersama dengan kelompok, mereka bekerjasama mengerjakan tugas sebaik mungkin, sehingga membuat suasana kelas menjadi lebih hidup. Mereka dapat dengan leluasa mengemukaan pendapat, bertanya, serta memberi komentar mengenai materi yang dibahas saat itu. Hasil ini sejalan dengan penelitian yang dilakukan oleh Ginting [20-27] menyimpulkan bahwa Penerapan model SQ4R dapat meningkatkan hasil bnelajar bahasa Indonesia siswa kelas V di SDN 38 medan johor tahun ajaran 2016/2017. Martinah [21] juga menyimpulkan bahwa terdapat pengaruh model pembelajaran SQ4R terhadap pemahaman konsep matematis siswa kelas VII SMP Negeri 2 lubuklinggau tahun pelajaran 2017/2018.

Faktor-faktor yang menyebabkan SQ4R kurang dalam meningkatkan hasil belajar Biologi siswa dari pada menggunakan model pembelajaran TTW dapat dilihat selama proses pembelajaran berlangsung yaitu; siswa cenderung bingung dan kurang mengerti dalam menerapkan sintak dari model pembelajaran SQ4R; hanya siswa yang aktif saja yang cenderung bertanya saat pembelajaran berlangsung guna menyelesaikan masalah yang diberikan, sedangkan siswa yang kurang aktif hanya menunggu jawaban dari temannya yang lebih aktif; siswa kurang bekerja sama dalam melakukan tugas kelompok yang diberikan oleh guru; serta siswa kurang hapal dalam melaksanakan sintak model pembelajaran yang digunakan; serta jumlah siswa pada kelas eksperimen II yang menggunakan model SQ4R lebih banyak dibandingkan dengan kelas yang menggunakan model pemebelajaran TTW sehingga murid kurang fokus dalam proses pembelajaran.

\section{KESIMPULAN}

Berdasarkan hasil penelitian dan pembahasan, dapat disimpulkan bahwa ada perbedaan antara hasil belajar Biologi siswa kelas
$\mathrm{X}$ pada penerapan model pembelajaran TTW dan model pembelajaran SQ4R di MA Al-Aziziyah Putri Kapek Gunungsari Tahun Ajaran 2017/2018. Hasil belajar Biologi pada kelas eksperimen I yang menggunakan model pembelajaran TTW memiliki peningkatan lebih tinggi dibandingkan kelas eksperimen II yang menggunakan model pemebelajaran SQ4R.

\section{DAFTAR PUSTAKA}

[1] Purwanto. 2014. Evaluasi Hasil Belajar. Yogyakarta : Pustaka Belajar.

[2] Hamdani. 2011. Dasar-Dasar Pendidikan . Bandung : Pustaka Setia.

[3] Depdiknas. 2003. Undang-Undang Nomor 20 Tahun 2003,Tentang Sistem Pendidikan Nasional. Jakarta: Depdiknas.

[4] Bayuaji, P., Hikmawati, H., \& Rahayu, S. (2017). Pengaruh Model Pembelajaran Kooperatif Tipe Student Facilitator And Explaining (Sfae) Dengan Pendekatan Saintifik Terhadap Hasil Belajar Fisika. Jurnal Pijar Mipa, 12(1).

[5] Al-idrus, S. Q. M. J., Hikmawati, H., \& Wahyudi, W. (2015). Pengaruh model pembelajaran berbasis masalah berbantuan video kartun terhadap hasil belajar fisika siswa kelas xi sman 1 sikur tahun ajaran 2014/2015. Jurnal Pijar MIPA, 10(1).

[6] Yulianti, R., Muntari, M., \& Haris, M. (2015). Pengaruh model pembelajaran kooperatif tipe two stay two stray (tsts) dengan pendekatan brain-based learning terhadap hasil belajar kimia materi pokok struktur atom dan sistem periodik unsur pada siswa kelas $\mathrm{x}$ sman 1 kediri. Jurnal pijar MIPA, 10(1).

[7] Widoyoko, Eko Putra. 2010. Evaluasi Program Pembelajaran. Yogyakarta : Pustaka Belajar.

[8] Purwanta, I Made Agus. 2013. Implementasi Model Pembelajaran Kooperatif Tipe Think Talk Write (TTW) Untuk Meningkatkan Hasil Belajar Siswa Kelas Vii B Smp N 3 Susut Pada Pokok Bahasan Ekosistem Tahun Ajaran 2012/2013. Skripsi. Denpasar : Universitas Mahasaraswati Denpasar. 
[9] Shoimin. 2014. 68 Model Pembelajaran Kooperatif Dalam Kurikulum 2013. Yogyakarta: Ar-Ruzz Media.

[10] Basri, Hasan. 2016. Penerapan Model Pembelajaran Think Talk Write (TTW) pada Pembelajaran Matematika Kelas VIII SMP Negeri Simpang Kosgoro Tahun Ajaran 2016/2017. Skripsi. Lubuk Linggau : STKIPPGRI Lubuk Linggau.

[11] Listiana, L. (2013, July). Pemberdayaan Keterampilan Berpikir dalam Pembelajaran Biologi melalui Model Kooperatif Tipe GI (Group Investigation) dan TTW (Think, Talk, Write). In Proceeding Biology Education Conference: Biology, Science, Enviromental, and Learning (Vol. 10, No. 1).

[12] Yanuarta, L., Waluyo, J., \& Suratno, S. (2014). Penerapan Model Pembelajaran Kooperatif Tipe Think, Talk, Write (Ttw) Dengan Teknik Talking Stick Dalam Meningkatkan Karakter Dan Hasil Belajar Ipa-Biologi (Siswa Kelas Vii-E Smp Negeri 2 Kalisat Semester Genap Tahun Ajaran 2012/2013). Pancaran Pendidikan,3(1), 6978.

[13] Juniasih, N. W., Jampel, I. N., \& Setuti, N. M. (2013). Pengaruh Model Pembelajaran Think Talk Write (TTW) Berbantuan Media Konkret Terhadap Hasil Belajar IPA Siswa Kelas IV SD. Mimbar PGSD Undiksha, 1(1).

[14] Nurhayati, W., Wardhayani, S., \& Ansori, I. (2012). Peningkatan Komunikasi Ilmiah Pembelajaran IPA Melalui Model Kooperatif Tipe Think Talk Write. Joyful Learning Journal, 1(1).

[15] Kusumaningrum, Diah. 2016. Pengaruh Model Pembelajran Think Talk Write (TTW) Terhadap Kemampuan Siswa Menyelesaikan Soal Cerita Pada Materi Pokok Fungsi Pada Siswa Kelas VIII SMP Negeri 1 Wonodadi. Skripsi. Kediri : Ubiversitas Nusantara.

[16] Prasetyani, Ulfi Dwi. 2010. Peningkatan Hasil Belajar Dengan Menggunakan Metode Pembelajaran SQ4R (Survey,Question, Read, Reflect, Recite,Review) Melalui Pendekatan Talking Stick Pada Mata Pelajaran Biologi Kelas Viii Pokok Bahasan Sistem Peredaran Darah Di Smp Negeri 31 Semarang. Skripsi. Semarang : Universitas negri Semarang.
[17] Rahayu, Putu Indah. 2014. Model Pembelajaran SQ4R Berbasis Keterampilan Proses Berpengaruh Terhadap Hasil Belajar IPA Siswa Kelas V SD Gugus Letkol Wisnu. Skripsi. Singaraja : Universitas Pendidikan Ganesha.

[18] Rasjid, Y. (2015). Pengaruh Model Pembelajaran Survey Question Read Reflect Recite Review (SQ4R) Dengan Metode Talking Stick Terhadap Keterampilan Metakognisi dan Hasil Belajar Biologi Siswa SMAN 9 Makassar. Jurnal Biotek, 3(2), 170183.

[19] Dewi, K. C. (2016). Peningkatan Aktivitas Dan Hasil Belajar Sistem Ekskresi Melalui Penerapan Model Pembelajaran SQ4R Bagi Siswa Kelas XI IPA 1 SMA Negeri 1 Cepiring Semester 2 Tahun Pelajaran 2015/2016. Majalah Ilmiah Inspiratif, 2(2).

[20] Nanda, Rizky. 2015. Pengaruh Penggunaan Model Pembelajaran SQ4R (Survey, Question, Read, Reflect, Recite, Review) Pada Pelajaran Ips Sejarah Terhadap Hasil Belajar Siswa Kelas VII Smp Empu Tantular Semarang Tahun Pelajaran 2014/2015. Skripsi. Semarang : Universitas negri Semarang.

[21] Herliani. 2013. Penerapan Model Pembelajaran Kooperatif Tipe Think, Talk, Write Dalam Upaya Meningkatkan Hasil Belajar dan Kemampuan Berpikir Kritis Siswa Pada Mata Pelajaran Biologi Di SMA 8 Samarinda. Skripsi. Samarinda : Universitas Mulawarman.

[22] Rojiah, Neng Siti. 2016. Pengaruh Model Pembelajaran Think, Talk, Write Terhadap Kemampuan Komunikasi Metakognisis Siswa SMP. e-Journal Universitas Pasuruan FKIP, Vol. 4, No. 2, hal 213-222, Mei 2016.

[23] Ningrum, A. S., Lestari, N., \& Kusmiyati, K. (2018). Perbedaan Hasil Belajar IPA Biologi Menggunakan Model Pembelajaran Kooperatif Tipe Team Assisted Individualization Dengan Tipe Mind Mapping Pada Siswa Kelas VII SMP Negeri 19 Mataram. Jurnal Pijar Mipa, 13(1), 37-44.

[24] Rahayu, Putu Indah. 2014. Model Pembelajaran SQ4R Berbasis Keterampilan Proses Berpengaruh Terhadap Hasil Belajar IPA Siswa Kelas V SD Gugus Letkol Wisnu. 
Skripsi. Singaraja : Universitas Pendidikan Ganesha.

[25] Ginting, Ifan Rose. 2017. Pengaruh Penerapan Model SQ4R Terhadap Hasil Belajar Bahasa Indonesia Siswa Kelas V di SDN 060938Medan Johar Tahun Ajaran 2016/2017. Skripsi. Medan : UNIMED.

[26] Mertinah, Iin. 2018. Pengaruh Model Pembelajaran Survey, Question, Read, Reflect, Recite, Review (SQ4R) Terhadap
Kemampuan Pemahaman Konsep Matematis Siswa Kelas VII SMP Negeri 2 Labuklinggau Tahun Ajaran 2017/2018. e-Journal Program Pascasarjana Sekolah Tinggi keguruan Labukliung, Vol 4.

[27] Gustina, D., Amsia, T., \& Ekwandari, Y. S. (2018). Pengaruh Model Pembelajaran Survey, Question, Read, Recite, Reflect, Review (SQ4R) terhadap Motivasi Belajar Siswa. PESAGI (Jurnal Pendidikan dan Penelitian Sejarah), 6(3). 